\title{
Hoffmann 創外固定器を用いた橈骨遠位端粉砕 骨折の治療経験
}

\author{
愛野記念病院整形外科 \\ 椇 林 葉子・平 野 英二 \\ 木 村 和也 \\ 長崎大学整形外科 \\ 角 光 宏 - 今 村 宏太郎 \\ 郡家病院整形外科 \\ 郡 家 則 之

\section{Haffmann-C type External Fixation Treatment for Comminuted Fractures of the Distal End of the Radius} \\ by \\ Yoko Narabayashi, Eiji Hirano and Kazuya Kimura \\ Department of Orthopaedic Surgery, \\ Aino Memorial Hospital \\ Mitsuhiro Sumi and Kotaro Imamura \\ Department of Orthopaedic Surgery, \\ Nagasaki University \\ Noriyuki Gunge \\ Gunge Hospital
}

We report 30 cases of comminuted fractures of the distal end of the radius treated with HoffmannC type external fixation.

The mean age of patients was 56 years (range, 29-79) years. The follow-up period ranged from 4 to 51 months, with a mean of 19 months. The external fixation device was used for about 4 weeks and then a short arm brace with the wrist in a neutral position was used for about 10 days. We added an other procedure, such as percutaneous fixation with $\mathrm{K}$-wire, or open reduction with bone graft or plating, when the reduction was not maintained solely by external fixation.

Anatomical and functional treatment results were good. According to Saito's point system, 26 cases were judged to be excellent, 3 cases were good, and 1 case was fair.

The Hoffmann-C type external fixation device is recommended for comminuted fractures of the distal end of the radius.

Key words : comminuted fractures of the distal end of radius（橈骨遠位端骨折）, external fixation (不安定型), Hoffmann（創外固定器） 
はじめに

橈骨遠位端粉砕骨折に対する治療法としての創外固 定の有用性は広く知られている所である。また近年で は術後早期より手関節の可動域訓練を行える Clyburn 型創外固定器などの dynamic type も使用されるよう になってきた。しかしながら, 従来より用いられてい る static type の代表である Hoffmann 創外固定器は 装着が簡便であり, また強固な固定性を持つという利 点を備えており捨て難い創外固定器であると考える. 我々は過去 5 年間に橈骨遠位端粉砕骨折に対し Hoffmann 創外固定器を用いた治療を行ってきた。今 回これらの症例の予後調查をもとに Hoffmann 創外 固定器の有用性について検討したので報告する.

\section{対象と方法}

対象は当院で過去 5 年間に Hoffmann 創外固定器 を用いて治療を行った橈骨遠位端粉䂶骨折 37 例中, 術後 4 力月以上経過し直接検診が行えた 29 例 30 骨折 である. 性別は男 9 例, 女 20 例, 年齢は 29 歳から 79 歳, 平均 56.2 歳であった。罹患側は右 13 例, 左 17 例でうち両側例は 1 例であった。受傷原因は転倒 16 例, 転落 11 例, 交通事故 2 例であった。追跡期間 は 4 力月から 4 年 3 力月, 平均 17.3 力月であった.

骨折型は Frykmann 分類に従った。III型 5 例, IV 型 10 例, V 型 1 例, VII型 7 例, VIII型 7 例であった.

治療法は徒手整復後 Hoffmann 創外固定器を約 4 週間装着し，その後手関節中間位前腕ギプスで 7 日間 固定した。ただし創外固定のみでは良好な解剖学的整 復位を得られない例には積極的に追加固定を行った。 創外固定のみを行ったものは 20 例, 経皮ピンニング を追加したものは 7 例, 観血整復と骨移植を追加した ものは 2 例, 内固定を追加したものは 1 例であった.

これらの症例を, $\mathrm{X}$ 線学的には ulnar variance, radial tilt, volar tilt を計測し受傷時, 術直後, 調査 時の值を比較した。 また斎藤のポイントシステムを用 いて術後成績の総合評価を行った。

\section{結果}

$\mathrm{X}$ 線学的評価では ulnar variance は受傷時平均 $3.6 \mathrm{~mm}$ と橈骨の短縮が見られたが, 術直後は平均 $0.7 \mathrm{~mm}$ とほほ解剖学的整復位が得られている. 調査 時には平均 $1.0 \mathrm{~mm}$ とやや短縮が見られる。 radial tilt
は術前平均 $13.7^{\circ}$ であったものが術後平均 $20.2^{\circ}$ と解剖 学的整復位を得, 調査時にも平均 $20.3^{\circ}$ とそれを保持 している.

volar tilt は術前平均 $-12.5^{\circ}$ とかなり背側に傾いて いるが術直後には平均 $8.0^{\circ}$ と解剖学的整復位を得, 調 査時には平均 $6.0^{\circ}$ となっている。なお関節症変化は認 めた例はなかった。

調査時の手関節の可動域は背屈平均 $74.8^{\circ}$, 掌届平 均 $72.6^{\circ}$, 橈屈平均 $17.4^{\circ}$, 尺屈平均 $27.1^{\circ}$, 回内平均 $83.6^{\circ}$, 回外平均 $82.4^{\circ}$ であった。

疼痛は RSD の 1 例に自発痛が見られ, 7 例に時及 疼痛があることがあり，そのほかは全く疼痛を訴えな かった．ADL 障害は RSD の 1 例を除きほとんど認

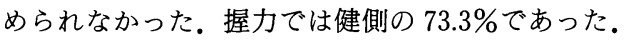

合併症は RSD を 1 例, Guyon 管症候群を 1 例に 2 認めた。感染例はなかった。

斎藤の評価成績判定基準では Excellent 26 例, Good 3 例, Fair 1 例であった。なお Fair の 1 例は RSD を合併したものであった.

\section{症例}

症例 $1: 32$ 歳, 男性, Frykmann $\mathrm{V}$ 型, 創外固定 単独で治療を行った（図 1). 受傷時 volar tilt- $32^{\circ}$

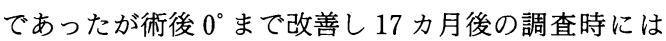
背側皮質の粉砕があったにもかかわらず良好な骨療合 が得られている。手関節可動域もほほ正常であった。 また総合評価はExcellent であった。背側皮質の粉砕 がある場合でも骨欠損がない時には創外固定だけで十 分であった。

症例 $2: 29$ 歳, 女性, Frykmann VII型. 創外固定 のみでは骨折部の安定と十分な整復位が得られず，1 カ月後全身麻酔下で観血整復と骨移植を行った（図 2). 29 力月後の調査時には健側とほほ同様の整復位が保 持されていた．総合評価は Excellent であった。この 症例のように骨欠損が大きな場合には一期的に骨移植 を積極的に行う必要があると思われた。

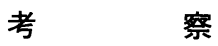

橈骨遠位端骨折は頻度の高い骨折であるが大部分の 症例は整復可能であり, ギプス固定でもよい結果が得 られる.しかし整復できてもその保持が困難なことが ある.このような不安定型骨折に対し, 創外固定は良 い適応となる。 


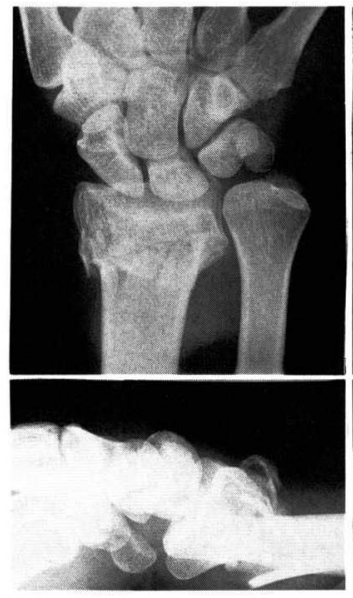

(a)

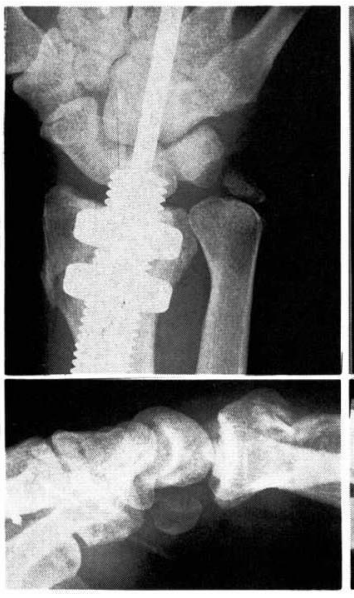

(b)

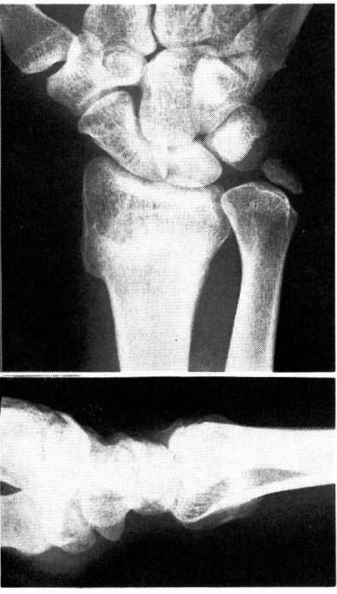

(c)

図 $1: 32$ 歳男性, Frykmann V 型, 創外固定単独治療郕.

a) 受傷時：volar tilt $-32^{\circ}$. 背側皮質の粉砕が認められる.

b) 創外固定装着時 : volar tilt $0^{\circ}$.

c） 17 力月後：整復位は保持されている.

創外固定の装着期間は諸家様々であり, 渡辺 ${ }^{4)}$ は 8 週間以内, Kaukonen ${ }^{2}$ は 6 週間, 佐々末 ${ }^{3)}$ は 5 週間と している。最も短いのは Abbaszadegan ${ }^{1)}$ で 4.4 週で ある.この場合問題になるのは早期に牽引を除去する ことによる骨折部の短縮であるが, Abbaszadeganの 症例では radial shortning は整復時 $0.2 \mathrm{~mm}$ であった ものが 4 週経過時 $1.9 \mathrm{~mm}$ となり創外固定抜去後 4 週 では $2.3 \mathrm{~mm}$ とさらに $0.4 \mathrm{~mm}$ の短縮が見られた. 我々 の症例でも創外固定は平均 4 週で意識的に早期に除去 し, その後 7 日間中間位前腕ギプス固定を行っている が, 先に述べたように ulnar variance は術直後平均 $0.7 \mathrm{~mm}$ が調查時平均 $1.0 \mathrm{~mm}$ と $0.3 \mathrm{~mm}$ の短縮が見ら れた.しかしその差はいずれも $1 \mathrm{~mm}$ 以内で実際には あまり問題にはならないと思われる. また創外固定除 去時には必ず透視下で骨折部の可動性を見ているが 4 週経過するとほとんど可動性は認められない. 牽引を 除去することで, 骨折部に適度の圧迫力が加わり骨瘾 合が促進されることを期待し，4 週間という早期に創 外固定を除去している。 また単に徒手整復と牽引だけ では整復位の保持が困難な場合には, 積極的に経皮的 にピンニングゃ骨移植を追加し整復位の獲得と安定性 の増大を目指している.

Hoffmann 創外固定の利点は装着が簡便であること, また強固な固定性を持つことにある.しかしながら不
良肢位での強固な固定は, 時に手関節の可動域制限お よび手指の拘縮をきたすとされている. そのため近年 術後早期より手関節の可動域訓練を行える Clyburn 型創外固定器などの dynamic type も使用されるよう になってきた。しかしながら, 今回の我々の調査結果 から, Hoffman 創外固定器によって強固な固定を行っ ても手関節の可動域制限をきたさず良好な結果を得る ことがわかった，従って，橈骨遠位端粉砕骨折に対し Hoffmann 創外固定器は橈骨の短縮が少なく手関節の 可動域制限もほとんどきたさず，十分に有用であると 思われる。

\section{ま と め}

1) Hoffmann 創外固定器を用いて治療を行った橈骨 遠位端粉砕骨折 29 例 30 骨折の臨床成績を検討した.

2) X 線上, 術後の良好な整復位は, 調査時にも保持 されていた。

3）しかし創外固定器だけでは整復位の獲得と保持が 困難な症例には追加手術が必要であった.

4) Hoffmann 創外固定器によって強固な固定を行っ ても手関節の可動域制限を来さず良好な臨床成績が得 られ，有用な治療法と考えられた。 

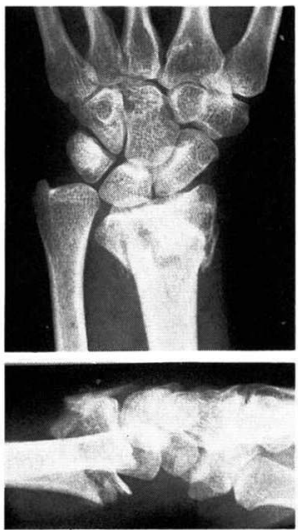

(a)
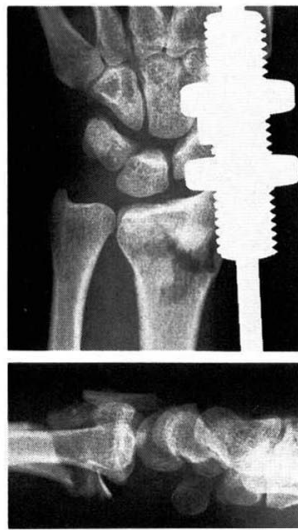

(b)
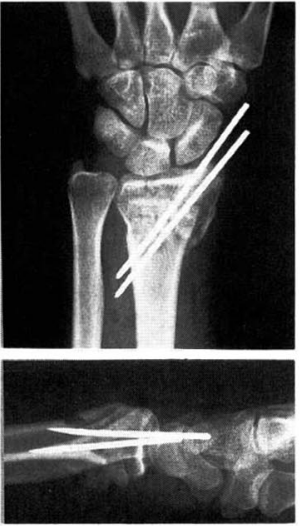

(c)
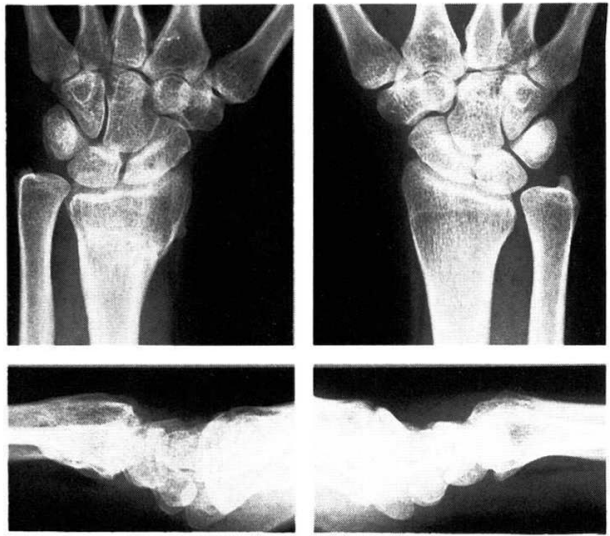

(d)

図 2：29 歳女性, Frykmann VII型, 骨移植追加例.

a) 受傷時 : volar tilt $-10^{\circ}$.

b）創外固定装着時：整復位は取れているが骨欠損 が見られる。

c) 骨移植時

d）調査時：健側とほぼ同様の形態が保たれている.

\section{参 考 文 献}

1) Abbaszadegan $\mathrm{H}$ : External fixation of plaster cast for severely displaced Colles's fracter? Acta Orthop Scand $1989: 60$ (6) : 646-50.

2) Kaukonen J P, K : External fixation of Colles' fracture. Acta Orthop Scand $1989: 60$ (1) 54-6.

3）佐々木孝他：橈骨遠位端骨折に対する創外固定. 日手 会誌. $3: 515-519,1986$.

4) 渡辺健太郎：橈骨遠位端骨折一新鮮例, 関節外一整形 外科 Mook No. 64, 1992. 